\title{
Nitrous oxide emissions following dairy shed effluent application beneath Kunzea robusta (Myrtaceae) trees
}

\author{
Hannah M. Franklin ${ }^{1,3}$, Roshean R. Woods ${ }^{2}$, Brett Robinson ${ }^{2}$, Nicholas Dickinson ${ }^{1}$ \\ 1 Department of Ecology, Lincoln University, PO Box 85084, Lincoln 7647, \\ Canterbury, New Zealand \\ 2 Department of Soil and Physical Sciences, Lincoln University, PO Box 85084, \\ Lincoln 7647, Canterbury, New Zealand \\ ${ }^{3}$ Australian Rivers Institute, Nathan Campus, Griffith University, 170 Kessels Road \\ Nathan, Queensland, 4111, Australia
}

Note on authorship: The first two authors contributed equally to practical work and to preparation of this manuscript.

Details of corresponding Author:

Hannah Franklin

Address: $\quad$ Australian Rivers Institute,

Nathan Campus,

Griffith University,

170 Kessels Road

Nathan, Queensland, 4111,

Australia

Email: h.franklin@griffith.edu.au

Telephone: +61 737354370

Fax: +61 737357615

Mobile: +61 415031384 
1 Abstract. Agriculture contributes more than a third of anthropogenic nitrous oxide

$2\left(\mathrm{~N}_{2} \mathrm{O}\right)$ emissions globally. In New Zealand, land application of dairy shed effluent

3 contributes to the $90 \%$ of $\mathrm{N}_{2} \mathrm{O}$ emitted from agricultural soils. Novel strategies are

4 urgently required to mitigate $\mathrm{N}_{2} \mathrm{O}$ production to ensure New Zealand's dairy-based

5 economy is environmentally sustainable. Species of Myrtaceae, including Kunzea spp.

6 (kānuka, white tea-tree) have previously been shown to produce antimicrobial

7 compounds which extend to the soil. It is possible that these may inhibit the microbes

8 involved in biological nitrification and denitrification which could thereby suppress

$9 \mathrm{~N}_{2} \mathrm{O}$ production. Therefore, in this work we aimed to test whether irrigation of effluents

10 to stands of Kunzea spp. could minimize resulting $\mathrm{N}_{2} \mathrm{O}$ emissions. This study

11 investigated soil inorganic $\mathrm{N}$ and $\mathrm{N}_{2} \mathrm{O}$ emissions following the application of dairy shed

12 effluent to soil beneath 5-yr-old K. robusta compared with bare soil. Following effluent

13 application, $\mathrm{N}_{2} \mathrm{O}$ emissions beneath $K$. robusta were reduced by $80 \%$ relative to bare

14 soil, but nitrate-N was five-fold higher than bare soil, sufficiently available for

15 denitrification. The drier, more aerated soil associated with $K$. robusta may have

16 constrained denitrification. Application of DSE (50 kg N ha-1) to K. robusta produced

$170.133 \mathrm{~kg} \mathrm{~N}_{2} \mathrm{O}-\mathrm{N} \mathrm{ha} \mathrm{H}^{-1}$ during the experimental period; equivalent to the lower range of

18 emissions measured following comparable applications to grazed dairy pastures in New

19 Zealand (0.13-1.08 $\left.\mathrm{kg} \mathrm{N} \mathrm{ha}^{-1}\right)$. The environmental benefits of reduced $\mathrm{N}_{2} \mathrm{O}$ emissions

20 warrant further investigation on the effect of Myrtaceae on the soil N cycle worldwide.

21 Keywords Greenhouse gas; Dairy farming; Nitrogen; Kānuka; Tea tree; sustainable

22 agriculture 


\section{Introduction}

24 Nitrous oxide $\left(\mathrm{N}_{2} \mathrm{O}\right)$ is a potent greenhouse gas with a global warming potential 298 times that of carbon dioxide (Myhre et al. 2013). New Zealand has a unique greenhouse gas profile where $93.4 \%$ of $\mathrm{N}_{2} \mathrm{O}$ emissions are from agricultural soils (Ministry for the Environment 2015). Land irrigation of dairy shed effluent (DSE) to pastures contributes to these $\mathrm{N}_{2} \mathrm{O}$ emissions and is commonplace in New Zealand. Dairy shed effluent is typically a high-nitrogen $(\mathrm{N})$ mixture of urine, dung, and wash-down water containing 44-628 mg N L ${ }^{-1}$; mostly in the form of organic N (Saggar et al. 2004).

Findings of a recent study suggest New Zealand members of the Myrtaceae family could mitigate the threat of microbial contamination of soil following the application of organic wastes (Prosser et al. 2016). The antimicrobial properties of Leptospermum (mānuka, tea-tree) and Kunzea (kānuka, white tea-tree) species were found to extend to the soil. However, this study did not consider soil N processes. Biological nitrification converts ammonium-N $\left(\mathrm{NH}_{4}^{+}\right)$in DSE to nitrate- $\mathrm{N}\left(\mathrm{NO}_{3}^{-}\right)$in soil, which is the substrate for $\mathrm{N}_{2} \mathrm{O}$ production via the nitrifier-denitrification and denitrification of anaerobic bacteria (Bolan et al. 2004). The antimicrobial properties of Myrtaceae could potentially influence these microbially driven soil $\mathrm{N}$ cycling processes and alter nitrate $\left(\mathrm{NO}_{3}{ }^{-}\right)$ production, denitrification and $\mathrm{N}_{2} \mathrm{O}$ emissions. In this study, we investigated the suitability of Kunzea robusta for the disposal of DSE in terms of $\mathrm{N}_{2} \mathrm{O}$ production. We hypothesized that application of DSE to K. robusta trees could reduce $\mathrm{N}_{2} \mathrm{O}$ emissions compared with application to bare soil. The aim of the present study was to

44 compare changes in $\mathrm{N}_{2} \mathrm{O}$ emissions and soil inorganic $\mathrm{N}$ concentrations from soil underneath Kunzea trees with bare soil areas following DSE application. We also 
compared $\mathrm{N}_{2} \mathrm{O}$ emissions from Kunzea with emissions data from previous studies of

47 DSE application to grazed pastures in New Zealand.

\section{Materials and methods}

\subsection{Site description}

50 Kunzea robusta is one of 10 species previously described as Kunzea ericoides (de Lange 2014). The experimental site was a fenced, planted corner of the Lincoln University Dairy Farm, Canterbury, New Zealand that was retired from grazing in 2008 (1800 m² $43^{\circ} 38 ' 38.07^{\prime \prime}$ S, $172^{\circ} 26^{\prime} 1.96 "$ E, described in Franklin et al. 2015). The soil type was a Templeton silt loam (Immature Pallic, Hewitt 1998; Udic Haplustept, Soil Survey Staff 2014). Kunzea robusta trees were around $2 \mathrm{~m}$ tall and 5 years old, with a 5-10 mm litter layer.

\subsection{Treatment and experimental design}

On 26 July 2012, headspace chamber bases (0.48 m diam., $0.18 \mathrm{~m}^{2}$, stainless steel) with an annular water trough were inserted $0.1 \mathrm{~m}$ into the soil (gas sampling plots, Fig. 1). During gas sampling events, insulated, stainless steel headspace covers created a gastight seal ( 0.14 $\mathrm{m}$ above the soil surface). Adjacent to each gas sampling chamber a metal ring (0.48 $\mathrm{m}$ diam., $\left.0.18 \mathrm{~m}^{2}\right)$ was inserted $0.1 \mathrm{~m}$ into the soil for destructive soil sampling (soil sampling plots, Fig. 1).

64 Five replicate $K$. robusta and bare soil locations (bare soil $>1 \mathrm{~m}$ from the drip line of trees) were randomly selected. Each location consisted of two subplots to which DSE or control was applied (Fig.1). Each subplot consisted of a pair of gas sampling/soil sampling plots (Fig. 1). Dairy shed effluent (450 $\mathrm{mg} \mathrm{N} \mathrm{L}^{-1}$ ) was applied at $50 \mathrm{~kg} \mathrm{~N} \mathrm{ha}^{-1}$

68 to DSE subplots and an equal volume of untreated tap water (1.5 $\mathrm{mg} \mathrm{NO}_{3}^{-}-\mathrm{N} \mathrm{L}^{-1}$ and

$690.05 \mathrm{mg} \mathrm{NH}_{4}{ }^{+}-\mathrm{N} \mathrm{L}^{-1}$ ) to the control subplots. Plots were established radially around 
K. robusta stems ( $0.2 \mathrm{~m}$ from the stem) and centers of bare soil locations, separated by $>0.2 \mathrm{~m}$, to avoid seepage between plots (Fig. 1). Treatments were applied to subplots (gas sampling/soil sampling pairs) randomly on the morning of 7 Aug. 2012. Dairy shed effluent was collected from the Lincoln University Dairy Farm storage pond on 9 Sept. 2011, homogenized, and stored at $5^{\circ} \mathrm{C}$ prior to use.

\subsection{Field sampling, analysis, and meteorological measurements}

Gas samples were taken the day prior to treatment application (Day 0), approximately 4 hours after DSE application (Day 1), and on following Days: 2, 3, 9, 16 and 23.

Sampling was conducted between 12:30 and 15:30 h. Headspace samples (10 mL) were taken manually 0, 20, and 40 min after positioning the cover and compressed into $6 \mathrm{~mL}$ Exetainer tubes (Labco Ltd., High Wycombe, UK). The headspace temperature was recorded in a representative chamber after initial checks found similarity between locations. Immediately prior to analysis, gas samples were brought to ambient pressure and $\mathrm{N}_{2} \mathrm{O}$ concentrations were determined using a gas chromatograph (GC, SRI 8610;

84 SRI Instruments, CA, USA) fitted with a ${ }^{63} \mathrm{Ni}$ electron capture detector (Gilson $222 \mathrm{XL}$; Gilson Inc., WI, USA) and calibrated using BOC $\alpha$ standards (BOC Scientific, New Zealand). Nitrous oxide fluxes were calculated following Hutchinson and Mosier (1981) after checking for linearity in $\mathrm{N}_{2} \mathrm{O}$ concentration over time. Cumulative $\mathrm{N}_{2} \mathrm{O}$ emissions were determined by integration.

Soil core samples $(2.5 \mathrm{~cm}$ diam. $\times 7.5 \mathrm{~cm}$ depth $)$ were taken to monitor soil gravimetric moisture content $\left(\theta_{\mathrm{g}}\right), \mathrm{pH}$, and inorganic-N concentrations. On Days: $0,2,3,9,16$, and

9123 three soil cores were taken at random, homogenized and sieved $(\leq 4 \mathrm{~mm})$. A

92 subsample was dried at $105^{\circ} \mathrm{C}$ for $24 \mathrm{~h}$ to determine $\theta_{\mathrm{g}}$. Soil $\mathrm{pH}$ was measured on field moist soil (10:25 soil:water). Another 4 g subsample of field moist soil was shaken with 
$9440 \mathrm{~mL}$ of $2 \mathrm{M} \mathrm{KCl}$ for $1 \mathrm{~h}$, centrifuged (10 min at $2000 \mathrm{rpm}$ ) and then filtered (Whatman

95 No. 41) (Blakemore et al. 1987). Extracts were analyzed for $\mathrm{NH}_{4}{ }^{+}-\mathrm{N}$ and $\mathrm{NO}_{3}{ }^{-}-\mathrm{N}$ by

96 flow injection analysis (FOSS FIAstar 5000 triple channel with SoFIA software version

97 1.30; Foss Tecator, Hoganas, Sweden). Total C and N were measured on air-dried

$98\left(35^{\circ} \mathrm{C}\right.$ for $\left.48 \mathrm{~h}\right)$, ground, and sieved (2 mm) soil using an Elementar Vario-Max CN

99 Elemental Analyzer (Elementar GmbH, Hanau, Germany). Total organic C was

100 measured using the loss on ignition method (Blakemore et al. 1987). Samples were also

101 analyzed for Olsen P following Olsen et al. (1954).

102 Soil bulk density was measured in K. robusta and bare soil locations in August 2015,

103 after the experimental period. There had been no stock access since the trial. Cores (5.4

$104 \mathrm{~cm}$ diam. $\times 5 \mathrm{~cm}$ depth) were carefully pressed into the soil. These were oven-dried

$105\left(>48 \mathrm{~h}\right.$ at $\left.105^{\circ} \mathrm{C}\right)$ to give $\theta_{\mathrm{g}}$ which was used to calculate bulk density $\left(\mathrm{g} \mathrm{cm}^{-3}\right)$. Soil

106 particle density was assumed to be $2.65 \mathrm{~g} \mathrm{~cm}^{-3}$. Water filled pore space (WFPS) was

107 calculated from these and $\theta_{\mathrm{g}}$ from the experimental period (Linn and Doran 1984).

108 2.4. Statistical analysis

109 Tests for normality showed the $\mathrm{N}_{2} \mathrm{O}$ flux data were skewed so these were log

110 transformed (Ln[flux]). Daily and cumulative $\mathrm{N}_{2} \mathrm{O}$ flux data were analyzed using

111 analysis of variance (ANOVA), with a split-split plot design, effectively a special case

112 of repeated measures ANOVA. Within whole plots (the 10 sampling locations),

113 treatments (DSE and control) were randomly assigned to split-plots (subplots each

114 consisting of a pair of gas/soil sampling plots). Within split-plots, sampling occurred on

115 multiple dates (split-split plots). Plot type (K. robusta and bare soil), treatment (DSE

116 and control) and time (Day) were factors. Three-way interactions were removed as the

117 interpretation of such effects is complex. Soil WFPS, $\mathrm{pH}, \mathrm{NO}_{3}{ }^{-}-\mathrm{N}$, and $\mathrm{NH}_{4}{ }^{+}-\mathrm{N}$ were 
118 analyzed in the same manner. Daily data were compared using ANOVA $(p<0.05)$ when

119 significant interactions with time occurred. Two-sample $t$ tests compared background

120 soil conditions between bare soil and K. robusta. Statistics were performed in R version

121 3.0.1 (R Development Core Team, 2010, Vienna, Austria, http://www.r-project.org/).

\section{3. Results}

\section{3.1. Nitrous oxide fluxes}

124 Prior to treatment application (Day 0) $\mathrm{N}_{2} \mathrm{O}$ flux was similar between locations (Fig. 2a).

125 K. robusta had significantly lower $\mathrm{N}_{2} \mathrm{O}$ fluxes compared with bare soil following DSE 126 application until after Day 9 (Fig. 2a). Plot type, treatment $(p<0.01)$ and sampling date

$127(p<0.05)$ significantly affected daily $\mathrm{N}_{2} \mathrm{O}$ flux, with the treatment effect changing 128 temporally (treatment $\mathrm{x}$ time, $p<0.05$ ). Nitrous oxide flux from $K$. robusta-DSE plots 129 rose significantly only on Day $1(p<0.001)$.

130 Cumulative $\mathrm{N}_{2} \mathrm{O}$ fluxes were higher $(p<0.001)$ from the bare soil-DSE plots $(676 \mathrm{~g}$ $131 \mathrm{~N}_{2} \mathrm{O}-\mathrm{N} \mathrm{ha}^{-1}$ or $1.35 \%$ of applied $\mathrm{N}$ ) compared with the bare soil-control (152 g N $\mathrm{N}_{2} \mathrm{O}-\mathrm{N}$

$\left.132 \mathrm{ha}^{-1}\right)$, K. robusta-DSE (133 g N $\mathrm{N}_{2} \mathrm{O}-\mathrm{N} \mathrm{ha}^{-1}$ or $0.27 \%$ of applied $\mathrm{N}$ ) and K. robusta-control

133 plots (95 g N $\left.\mathrm{g}_{2} \mathrm{O}-\mathrm{N} \mathrm{ha}^{-1}\right)$, which were similar. Plot type $(p<0.01)$, treatment $(p<0.05)$,

134 time $(p<0.001)$, and the plot type $\mathrm{x}$ treatment interaction $(p<0.01)$ were significant.

135 3.2. Soil and meteorological conditions

136 Background soil $\mathrm{pH}$, total $\mathrm{N}, \theta_{\mathrm{g}}$ and WFPS were higher in bare soil locations, while 137 total organic $\mathrm{C}$ and $\mathrm{NO}_{3}{ }^{-}-\mathrm{N}$ were more concentrated beneath $K$. robusta (Table 1 ). Soil 138 bulk density, total C, Olsen-P and $\mathrm{NH}_{4}{ }^{+}-\mathrm{N}$ did not differ between $\mathrm{K}$. robusta and bare 139 soil (Table 1). 
140 K. robusta plots had significantly lower $(p<0.001)$ WFPS than the bare soil plots (Fig.

141 2b), however, WFPS did not vary due to treatment (DSE or control) or time. Mean daily

$142 \theta_{\mathrm{g}}$ ranged from $27-32 \%$ for K. robusta and 31- 35\% for bare soil plots. A total of 104

$143 \mathrm{~mm}$ of rain fell during the experiment, consisting of one substantial event (75 mm, Day

144 8-10, Fig. 2b). The mean daily air temperature ranged from 6.7 to $14.9^{\circ} \mathrm{C}$ (Fig. 2b) and

145 a spike later in the experiment corresponded to a decrease in soil moisture. Throughout

146 the experiment soil $\mathrm{pH}$ was higher $(p<0.05)$ in the bare soil (mean of $5.8 \pm 0.02)$ than

$147 K$. robusta plots (5.5 \pm 0.03 ), while treatment (DSE or control) and time did not affect

$148 \mathrm{pH}$.

149 Soil $\mathrm{NO}_{3}^{-}-\mathrm{N}$ concentrations were higher $(p<0.01)$ in the $K$. robusta plots than bare soil

150 (Fig. 3a) and were not affected by treatment or time. Ammonium-N concentrations were

151 significantly higher $(p<0.05)$ in DSE than control plots, but did not differ between

152 K. robusta and bare soil (Fig. 3b). Ammonium-N was similar in all plots at the start of

153 the experiment (Fig. 3b) and increased following treatment application $(p<0.001)$, but

154 more so in DSE plots (treatment $\mathrm{x}$ time, $p<0.01$ ). Ammonium-N spiked in control plots

155 on Day 16 to match levels in DSE plots.

\section{4. Discussion}

157 4.1. Low nitrous oxide emissions under K. robusta

158 Cumulative $\mathrm{N}_{2} \mathrm{O}$ emissions following effluent application were $80 \%$ lower beneath

159 K. robusta relative to the bare soil. No other studies have investigated $\mathrm{N}_{2} \mathrm{O}$ emissions

160 from soil planted with $K$. robusta receiving DSE. Mean $\mathrm{N}_{2} \mathrm{O}$ emissions from K. robusta

161 locations (0.095 and $0.133 \mathrm{~kg} \mathrm{~N} \mathrm{ha}^{-1}$ for control and DSE respectively) during the

162 experimental period were close to background rates reported under Kunzea spp.

163 elsewhere (below detection limits, Price et al. 2010, and $0.30 \mathrm{~kg} \mathrm{~N} \mathrm{ha}^{-1} \mathrm{yr}^{-1}$, Hedley et 
165 24-day experimental period (0.133 $\mathrm{kg} \mathrm{N}_{2} \mathrm{O}-\mathrm{N} \mathrm{ha}^{-1}, 0.27 \%$ of $\mathrm{N}$ applied) were at the low

166 end of those found in the literature for similar DSE applications to grazed pastures in

167 New Zealand (0.13-1.08 $\left.\mathrm{kg} \mathrm{N} \mathrm{ha}^{-1}\right)$. Following applications of 50-60 $\mathrm{kg} \mathrm{N} \mathrm{ha}^{-1} \mathrm{DSE}$

$168 \mathrm{~N}_{2} \mathrm{O}$ was emitted at rates of $0.13-0.48(0.25-0.8 \%$ of $\mathrm{N}$ applied, Li et al. 2015) and

$169 \quad 0.15-0.45 \mathrm{~kg} \mathrm{~N} \mathrm{ha}^{-1}$ (0.31-0.73\% of $\mathrm{N}$ applied, Bhandral et al. 2007) during

170 approximately 20 and 2 week experimental periods, respectively. While consecutive

171 annual DSE applications of 56 and $43 \mathrm{~kg} \mathrm{~N} \mathrm{ha}^{-1}$ in the Canterbury region produced

1720.665 and $1.08 \mathrm{~kg} \mathrm{~N}_{2} \mathrm{O}-\mathrm{N} \mathrm{ha}^{-1} \mathrm{yr}^{-1}$ (1.2 and 2.5\% of $\mathrm{N}$ applied, van der Weerden et al.

173 2016). Consistent with the current study, others also report $\mathrm{N}_{2} \mathrm{O}$ emissions returning to

174 background levels rapidly (<3 weeks) following effluent application (Barton and

175 Schipper 2001; Bhandral et al. 2010).

176

177

178

179

180

181

182

183

184

185

186

187

\subsection{Soil conditions and nitrous oxide emissions}

Water filled pore space was around 10\% higher in bare soil than beneath K. robusta, likely due to transpiration by $K$. robusta and canopy rainfall interception. This was within the range suitable for denitrification (60-65\%, Linn and Doran 1984), however, WFPS in K. robusta plots were below this range. The corresponding aerobic conditions may have decreased $\mathrm{N}_{2} \mathrm{O}$-reductase activity in denitrification (Bakken and Dörsch 2007) and potentially contributed to reduced emissions. Soil moisture has previously been associated with variation in $\mathrm{N}_{2} \mathrm{O}$ emissions from Kunzea forests (Hedley et al. 2013). The dry sites which Kunzea spp. often dominate may explain the low reported background $\mathrm{N}_{2} \mathrm{O}$ production rates (Hedley et al. 2013; Price et al. 2010). The control treatment effectively accounted for increased soil moisture resulting from the DSE addition. However, WFPS did not increase in response to an event totaling $10 \%$ annual 
rainfall, it is possible that surface cracks channeled rainfall to groundwater or sampling dates missed a peak.

190 Soil pH was around 0.3 units lower beneath $K$. robusta, potentially through exudation of organic acids by K. robusta roots or breakdown of leaf litter. Denitrification rates are reduced in acidic conditions (van der Weerden et al. 1999), providing another possible explanation for reduced emissions. Kunzea robusta leaf litter at this site had a C:N ratio

194 of 26 (Zhong et al. 2014) so some mineralization was likely, as reflected in the elevated 195 soil organic C (Table 1).

196 Ammonium-N increased 10-fold immediately following DSE application likely due to 197 the high $\mathrm{NH}_{4}^{+}$concentrations in the DSE. Plant uptake, microbial immobilization, or 198 oxidization to $\mathrm{NO}_{3}{ }^{-}$may have then reduced the $\mathrm{NH}_{4}{ }^{+}$pool over time. Loss of $\mathrm{NH}_{4}^{+}$ 199 through volatilization, is unlikely due to the low soil pH (Bolan et al. 2004). 200 Ammonium-N also increased following water treatment possibly due to mineralization 201 of soil organic matter, while rainfall may explain $\mathrm{NH}_{4}{ }^{+}-\mathrm{N}$ variability during the 202 experiment. The peak in soil $\mathrm{NO}_{3}{ }^{-}-\mathrm{N}$ following treatment application to K. robusta may 203 be a result of increased $\mathrm{NO}_{3}{ }^{-}$retention. The rainfall event reduced soil $\mathrm{NO}_{3}{ }^{-}-\mathrm{N}$ 204 concentrations beneath $K$. robusta to levels comparable to bare soil.

205 The comparatively higher $\mathrm{NO}_{3}{ }^{-}-\mathrm{N}$ under $K$. robusta may mean that the reduced $\mathrm{N}_{2} \mathrm{O}$ 206 emissions were not the result of inhibition of nitrifying bacteria, but rather inhibition of 207 denitrifying bacteria. Despite available $\mathrm{NO}_{3}{ }^{-}$and $\mathrm{C}$ substrate for denitrification, 208 K. robusta soil emitted less $\mathrm{N}_{2} \mathrm{O}$ than bare soil. It seems likely that the dry, aerated, and 209 acidic soil under $K$. robusta was less suitable for $\mathrm{N}_{2} \mathrm{O}$ production via denitrification.

210 Differences in WFPS between K. robusta and bare soil confound the interpretation, 
211 meaning we cannot conclude whether inhibition of nitrification or denitrification

212 occurred.

\section{4.3. Implications for future Myrtaceae research}

214 We identified a significant reduction in $\mathrm{N}_{2} \mathrm{O}$ production from soil beneath $K$. robusta

215 following application of DSE, compared with bare soil. Constraints on the

216 denitrification process in the dry K. robusta soil are a possible cause of reduced

217 emissions (Hedley et al. 2013; Price et al. 2010). Nitrous oxide emissions from $K$.

218 robusta were low compared to those following similar applications to dairy pastures,

219 which typically have higher WFPS than that measured beneath $K$. robusta (Bhandral et

220 al. 2007, Li et al. 2015). Irrigation of DSE onto K. robusta plantations may offer a

221 sustainable disposal option for this high $\mathrm{N}$ waste, resulting in low $\mathrm{N}_{2} \mathrm{O}$ emissions, even

222 in the winter when emissions are typically higher. This would require a closed canopy

223 prior to DSE application to minimize exposed bare soil which is likely to emit more

$224 \mathrm{~N}_{2} \mathrm{O}$. Kunzea plantations may also provide additional income to farms through the

225 production of high value tea-tree oils and honey (Stephens et al. 2010). Other

226 Myrtaceae, Eucalyptus (Tzanakakis et al. 2009) and Melaleuca spp. (Bolton and

227 Greenway 1999), have been successfully used in effluent land treatment systems to

228 mitigate $\mathrm{NO}_{3}{ }^{-}$leaching and produce harvestable biomass, but associated $\mathrm{N}_{2} \mathrm{O}$ emissions

229 have not been investigated. Although suppression of denitrification is desirable,

230 pollution swapping may occur through increased $\mathrm{NO}_{3}{ }^{-}$leaching. Kunzea robusta

231 seedlings have demonstrated a capacity for luxury N uptake (Franklin et al. 2015).

232 Nitrogen storage in K. robusta roots, wood and foliage may reduce the pool of soil

233 nitrate available for both denitrification to $\mathrm{N}_{2} \mathrm{O}$, and $\mathrm{NO}_{3}{ }^{-}$leaching. Further research

234 should simultaneously measure $\mathrm{N}_{2} \mathrm{O}$ emissions, $\mathrm{NO}_{3}{ }^{-}$leaching and $\mathrm{N}$ uptake by $K$. 
robusta, to determine the net environmental effect of DSE irrigation onto K. robusta. In

addition, future work should incorporate comparisons to other tree and grassland

species to determine if this effect is unique to K. robusta. The environmental benefits of

reduced $\mathrm{N}_{2} \mathrm{O}$ emissions warrant a closer look at the effect of Myrtaceae on the soil $\mathrm{N}$

cycle worldwide.

\section{Acknowledgements}

241 This research was funded by Lincoln University. The authors wish to thank Manjula

242 Premaratne, Qian Liang, Roger Atkinson and Trevor Hendry (Faculty of Agriculture and Life Sciences, Lincoln University) for valuable technical assistance, as well as

Professor Tim Clough and two anonymous reviewers for comments on the manuscript draft.

\section{References}

Bakken LR, Dörsch P (2007) Nitrous oxide emission and global changes: modelling approaches. In: Bothe H, Ferguson SJ, Newton WE (eds) Biology of the nitrogen cycle. Elsevier, Amsterdam, The Netherlands, pp 382-395

Barton L, Schipper LA (2001) Regulation of nitrous oxide emissions from soils irrigated with dairy farm effluent. J Environ Qual 30:1881-1887 doi:10.2134/jeq2001.1881

Bhandral R, Bolan NS, Saggar S (2010) Nitrous oxide emission from farm dairy effluent application in grazed grassland. Revista de la ciencia del suelo y nutrición vegetal 10:22-34 doi:10.4067/S0718-27912010000100003

Bhandral R, Bolan NS, Saggar S, Hedley MJ (2007) Nitrogen transformation and nitrous oxide emissions from various types of farm effluents. Nutr Cycl Agroecosys 79:193-208 doi:10.1007/s10705-007-9107-5

Blakemore LC, Searle PL, Daly BK (1987) Methods for Chemical Analysis of Soils. New Zealand Soil Bureau Report. New Zealand Soil Bureau, Lower Hutt, New Zealand

Bolan NS, Saggar S, Luo JF, Bhandral R, Singh J (2004) Gaseous emissions of nitrogen from grazed pastures: processes, measurements and modelling, environmental implications, and mitigation. Adv Agron 84:37-120 doi:10.1016/s00652113(04)84002-1 
Bolton KGE, Greenway M (1999) Nutrient sinks in a constructed Melaleuca wetland receiving secondary treated effluent. Water Sci Technol 40:341-347 doi:10.1016/S0273-1223(99)00470-9

de Lange PJ (2014) A revision of the New Zealand Kunzea ericoides (Myrtaceae) complex. PhytoKeys 40:1-185 doi:10.3897/phytokeys.40.7973

Franklin HM, Dickinson NM, Esnault CJ, Robinson BH (2015) Native plants and nitrogen in agricultural landscapes of New Zealand. Plant Soil 394:407-420 doi:10.1007/s11104-015-2622-2

Hedley CB, Lambie SM, Dando JL (2013) Edaphic and environmental controls of soil respiration and related soil processes under two contrasting manuka and kanuka shrubland stands in North Island, New Zealand. Soil Res 51:390-405 doi:10.1071/SR12248

Hewitt AE (1998) New Zealand soil classification. Landcare Research Science Series, 2nd edn. Manaaki Whenua Press, Lincoln, New Zealand

Hutchinson GL, Mosier AR (1981) Improved soil cover method for field measurement of nitrous-oxide fluxes. Soil Sci Soc Am J 45:311-316 doi:10.2136/sssaj1981.03615995004500020017x

Li J, Luo J, Shi Y, Lindsey S, Houlbrooke D, Ledgard S (2015) Nitrous oxide emissions from dairy farm effluent applied to a New Zealand pasture soil. Soil Use Manage 31:279-289 doi:10.1111/sum.12187

Linn DM, Doran JW (1984) Effect of water-filled pore space on carbon dioxide and nitrous oxide production in tilled and nontilled soils. Soil Sci Soc Am J 48:12671272 doi:10.2136/sssaj1984.03615995004800060013x

Ministry for the Environment (2015) New Zealand's Greenhouse Gas Inventory 19902013. Ministry for the Environment, Wellington, New Zealand

Myhre G et al. (2013) Anthropogenic and Natural Radiative Forcing. In: Stocker TF et al. (eds) Climate Change 2013: The Physical Science Basis. Contribution of Working Group I to the Fifth Assessment Report of the Intergovernmental Panel on Climate Change. Cambridge University Press, Cambridge, United Kingdom and New York, NY, USA,

Olsen SR, Cole CV, Watanabe FS, Deans LA (1954) Estimation of available phosphorus in soils by extraction with sodium bicarbonate.

Price S, Whitehead D, Sherlock R, McSeveny T, Rogers G (2010) Net exchange of greenhouse gases from soils in an unimproved pasture and regenerating indigenous Kunzea ericoides shrubland in New Zealand. Soil Research 48(5), 385-394 doi:10.1071/SR09156

Prosser JA, Woods RR, Horswell J, Robinson BH (2016) The potential in-situ antimicrobial ability of Myrtaceae plant species on pathogens in soil. Soil Biol Biochem 96:1-3 doi:10.1016/j.soilbio.2015.12.007

Saggar S, Bolan NS, Bhandral R, Hedley CB, Luo J (2004) A review of emissions of methane, ammonia, and nitrous oxide from animal excreta deposition and farm effluent application in grazed pastures. New Zeal J Agr Res 47:513-544 doi:10.1080/00288233.2004.9513618

Soil Survey Staff (2014) Keys to Soil Taxonomy. 12th edn. USDA-Natural Resources Conservation Service, Washington, DC 
Stephens JM, Schlothauer RC, Morris BD, Yang D, Fearnley L, Greenwood DR, Loomes KM (2010) Phenolic compounds and methylglyoxal in some New Zealand manuka and kanuka honeys. Food Chem 120:78-86 doi:10.1016/j.foodchem.2009.09.074

Tzanakakis VA, Paranychianakis NV, Angelakis AN (2009) Nutrient removal and biomass production in land treatment systems receiving domestic effluent. Ecol Eng 35:1485-1492 doi:10.1016/j.ecoleng.2009.06.009

van der Weerden TJ et al. (2016) Nitrous oxide emissions from urea fertiliser and effluent with and without inhibitors applied to pasture. Agri Ecosys Environ 219:58-70 doi:http://dx.doi.org/10.1016/j.agee.2015.12.006

van der Weerden TJ, Sherlock RR, Williams PH, Cameron KC (1999) Nitrous oxide emissions and methane oxidation by soil following cultivation of two different leguminous pastures. Biol Fert Soil 30:52-60 doi:10.1007/s003740050587

Zhong H, Kim Y-N, Smith C, Robinson B, Dickinson N Does rhizosphere and litter diversity mediate the biogeochemistry of restoration soils? In: 20th WORLD CONGRESS OF SOIL SCIENCE, Jeju, South Korea, 2014. pp 304-304 


\section{Tables}

328 Table 1

329 Chemical and physical properties for the Templeton silt loam soil at the study site under

330 Kunzea robusta and bare soil locations and of the dairy shed effluent. Data are mean

331 ( \pm SE). Soil (0-7.5 cm depth) was collected from K. robusta and bare soil locations

332 adjacent to sampling plots $\left(n=5\right.$, except $\mathrm{pH}, \mathrm{NO}_{3}{ }^{-}-\mathrm{N}, \mathrm{NH}_{4}{ }^{+}-\mathrm{N}$ and gravimetric moisture

333 content where $\mathrm{n}=10$ ). Significant differences between $K$. robusta and bare soil locations

334 are indicated.

\begin{tabular}{|c|c|c|c|c|c|c|}
\hline \multirow[b]{2}{*}{$\mathrm{pH}$} & \multicolumn{3}{|c|}{ Bare Soil } & \multicolumn{2}{|c|}{$\begin{array}{c}\text { Kunzea robusta } \\
\text { (kānuka) }\end{array}$} & \multirow{2}{*}{$\begin{array}{c}\begin{array}{c}\text { Dairy shed } \\
\text { effluent }\end{array} \\
7.5\end{array}$} \\
\hline & 5.5 & $(0.04)$ & $* * *$ & 5.3 & $(0.05)$ & \\
\hline $\mathrm{C}\left(\mathrm{mg} \mathrm{g}^{-1}\right)$ & 29.9 & $(0.47)$ & $\mathrm{NS}^{\ddagger}$ & 28.5 & $(0.60)$ & $1070(95)^{\dagger}$ \\
\hline $\mathrm{N}\left(\mathrm{mg} \mathrm{g}^{-1}\right)$ & 2.94 & $(0.04)$ & $*$ & 2.68 & $(0.09)$ & $450(45)^{\dagger}$ \\
\hline Organic C (mg g $\left.{ }^{-1}\right)$ & 5.99 & $(0.85)$ & * & 7.78 & $(0.17)$ & \\
\hline $\mathrm{C}: \mathrm{N}$ & 10.2 & $(0.11)$ & NS & 10.7 & $(0.33)$ & \\
\hline $\mathrm{NO}_{3}{ }^{-}-\mathrm{N}\left(\mu \mathrm{g} \mathrm{g}^{-1}\right)$ & 7.04 & $(3.28)$ & $*$ & 17.4 & $(4.03)$ & $0.25(0.01)$ \\
\hline $\mathrm{NH}_{4}{ }^{+}-\mathrm{N}\left(\mu \mathrm{g} \mathrm{g}^{-1}\right)$ & 0.70 & $(0.53)$ & $\mathrm{NS}^{\ddagger}$ & 1.32 & $(0.91)$ & $244.9(6.00)$ \\
\hline Olsen P (mg L $\left.{ }^{-1}\right)$ & 19.0 & $(1.21)$ & NS & 17.8 & $(1.67)$ & \\
\hline Gravimetric moisture content (\%) & 31.4 & $(0.74)$ & $*$ & 28.9 & $(0.64)$ & \\
\hline Bulk density $\left(\mathrm{g} \mathrm{cm}^{-3}\right)$ & 1.11 & $(0.03)$ & NS & 1.01 & $(0.04)$ & \\
\hline Water filled pore space (\%) & 59.6 & $(1.40)$ & $* * *$ & 46.9 & $(1.04)$ & \\
\hline
\end{tabular}

$335 *$ Significant at the 0.05 probability level.

$336 * * *$ Significant at the 0.001 probability level.

$337 \dagger$ Units are $\mu \mathrm{g} \mathrm{g}^{-1}$ for $\mathrm{C}$ and $\mathrm{N}$ of dairy shed effluent.

$338 \mp$ NS, nonsignificant. 


\section{Figure Captions}

$340 \quad$ Figure 1

341 The arrangement of dairy shed effluent (DSE) and control subplots in bare soil and $K$.

342 robusta locations. Each subplot includes a paired gas sampling chamber and soil

343 sampling plot (each $0.48 \mathrm{~m}$ diam.) to which DSE or control treatments were applied.

344 Sampling plots were placed $0.2 \mathrm{~m}$ away from the stems of $K$. robusta (X) and centre of

345 bare soil plots.

346 Figure 2

347 Mean $\left( \pm\right.$ SE) daily $\mathrm{N}_{2} \mathrm{O}-\mathrm{N}$ flux (a) and mean $( \pm \mathrm{SE})$ water filled pore space and

348 meteorological measurements (b) following the application of dairy shed effluent (DSE,

$34950 \mathrm{~kg} \mathrm{~N} \mathrm{ha}^{-1}$ ) and control treatments to K. robusta and bare soil plots (n=5).

350 Meteorological data were obtained from the nearby NIWA Broadfield Climate Station

351 (43 $37^{\prime} 34.4^{\prime \prime}$ S, $172^{\circ} 28^{\prime} 13.4$ E). Water filled pore space data are for control plots only,

352 dairy shed effluent plots not shown (no effect of treatment type).

353 Figure 3

354 Mean $( \pm \mathrm{SE})$ soil $\mathrm{NO}_{3}{ }^{-}-\mathrm{N}(\mathrm{a})$ and $\mathrm{NH}_{4}{ }^{+}-\mathrm{N}$ (b) concentration ( $\mu \mathrm{g} \mathrm{g}^{1}$ of soil, 0-7.5 cm

355 depth) over time, following the application of dairy shed effluent (DSE, $50 \mathrm{~kg} \mathrm{~N} \mathrm{ha}^{-1}$ )

356 and control to bare soil and K. robusta plots (n=5). 


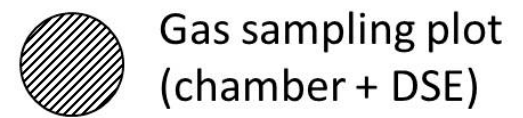

Gas sampling plot (chamber + control)

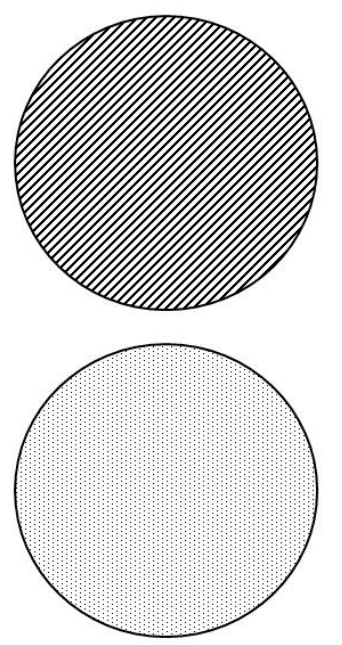

Bare soil
Soil sampling plot

(ring + DSE)

Soil sampling plot

(ring + control)

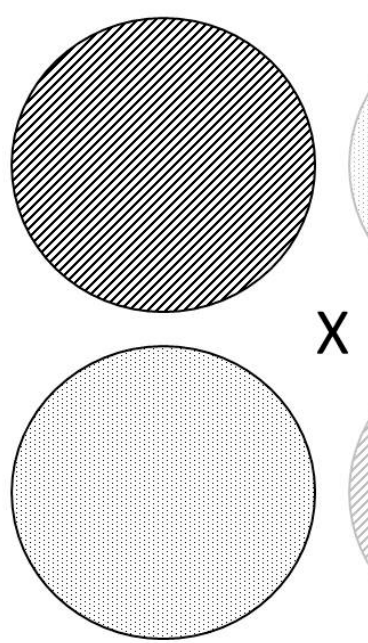

Kunzea robusta 
Figure 2
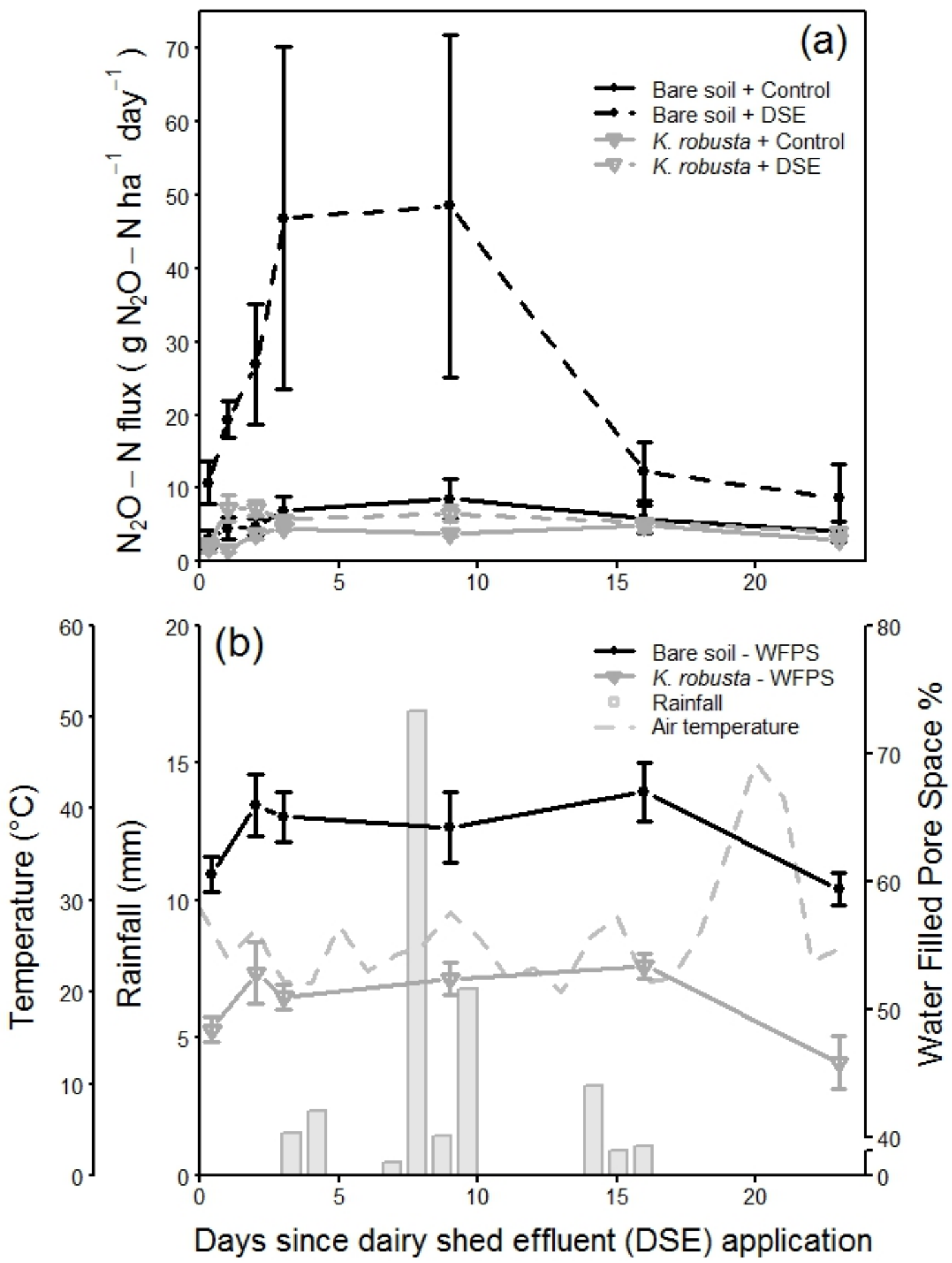
Figure 3
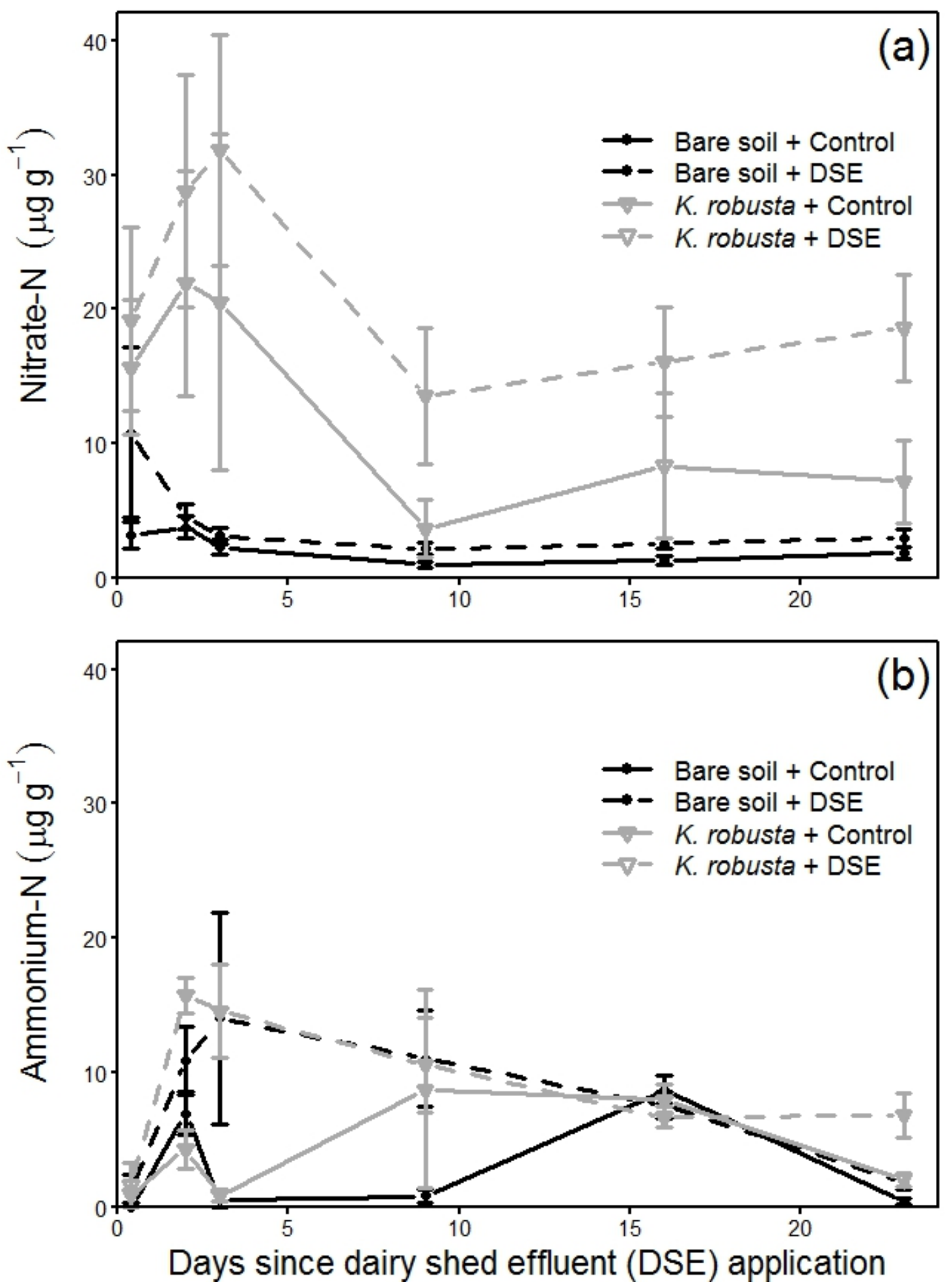